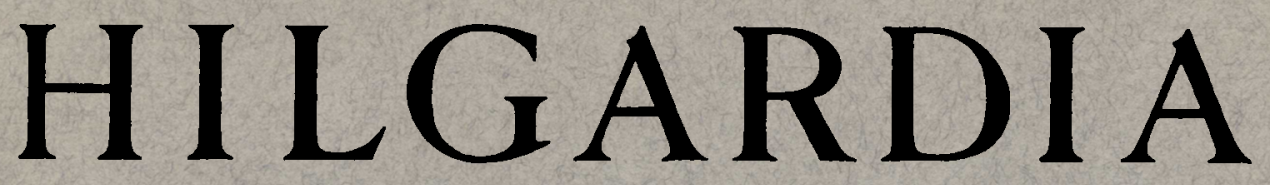

A Journal of Agricultural Science Published by the California Agricultural Experiment Station

THE CONNECTION BETWEEN DEMATOPHORA NECATRIX AND ROSELLINIA NECATRIX

H. N. HANSEN, HAROLD E. THOMAS, AND H. EARL THOMAS

A BACTERIAL GALL DISEASE OF DOUGLAS FIR, PSEUDOTSUGA TAXIFOLIA

H. N. HANSEN AND RALPH E. SMITH

APPLE MOSAIC

H. EARL THOMAS

UNIVERSITY OF CALIFORNIA • BERKELEY, CALIFORNIA 


\section{THE CONNECTION BETWEEN DEMATOPHORA NECATRIX AND ROSELLINIA NECATRIX}

H. N. HANSEN, HAROLD E. THOMAS, AND H. EARL THOMAS

\section{A BACTERIAL GALL DISEASE OF DOUGLAS FIR, PSEUDOTSUGA TAXIFOLIA}

H. N. HANSEN AND RALPH E. SMITH

\section{APPLE MOSAIC}

H. EARL THOMAS 

APPLE MOSAIC

H. EARL THOMAS 



\title{
APPLE MOSAIC
}

\author{
H. EARL THOMAS ${ }^{2}$
}

AN INFECTIOUS VARIEGATION of apple foliage seems to have been recognized by Vibert in France as early as $1835 .{ }^{3}$ Earlier reports from the northeastern United States recently reviewed ${ }^{(1) 4}$ indicate that mosaic of apple is general in that area, though seldom if ever destructive. Mottled apple foliage has been noted in the State of Washington, ${ }^{(3,4)}$ some of which may represent the disease under consideration here. A mosaic type of disease which is probably distinct has been found on an ornamental apple in Kentucky. ${ }^{(9)} \mathrm{A}$ report ${ }^{(2)}$ of apple mosaic has appeared from Bulgaria, but the illustrations accompanying it are more characteristic of noninfectious types of chlorosis.

Specimens of mosaic in the variety Ranier were received from Paradise, California, in June, 1932. The trees had been purchased from a nursery in the State of Washington about five years earlier. In August, 1936, a single tree of Smith Cider obtained from a local nursery was found affected in a garden at Berkeley. Some of the affected trees or branches in the orchard at Paradise show, in addition to the direct loss of functional leaf area, a sparseness of foliage and reduction of terminal growth which seems to be chargeable to the mosaic disease.

\section{PLANTS AFFECTED AND SYMPTOMS}

Heretofore the disease has apparently been known only on the cultivated apple, Pyrus malus. On this plant, the typical symptoms have been amply illustrated ${ }^{(6,1)}$ (fig. 1). In addition to the symptoms commonly seen on the apple, there occasionally appears a complete chlorosis of the larger veins (vein clearing) while the remainder of the leaf retains the normal form and color. ${ }^{(\theta)}$ Of particular interest is the tendency of the chlorotic areas to be entirely killed both at Paradise and Berkeley during the summer months of intense sunlight.

In addition to the varieties Ranier, Smith Cider, and Starking, on which natural infection has been seen in California, all of the following developed symptoms when inoculated by grafting: Golden Delicious, Gravenstein, Lady, Tompkins King, White Pearmain, and Yellow New-

\footnotetext{
${ }^{1}$ Received for publication December 16, 1936.

${ }^{2}$ Associate Plant Pathologist in the Experiment Station.

${ }^{3}$ Reported by Bradford and Joley. ${ }^{(1)}$ Original not seen by the writer.

"Superscript numbers in parentheses refer to "Literature Cited" at the end of this paper.
} 
town. Several other varieties, including Yellow Bellflower are already on record ${ }^{(1)}$ as susceptible.

Since a rather large number of the relatives of the apple are grown in California for fruit or ornament, several experiments were made to determine whether some of these might be susceptible to the mosaic of apple. Inoculations were made by grafting buds, scions, or inarches

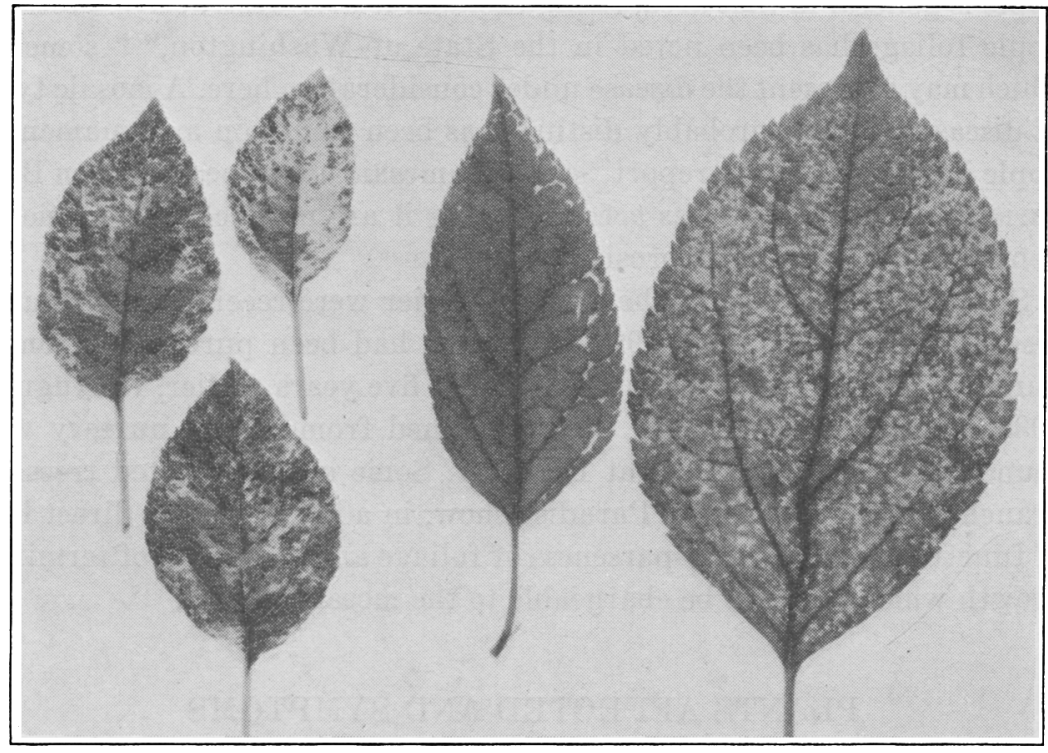

Fig. 1. - The two larger leaves at the right (White Astrachan) are affected by mosaic. The three smaller leaves (Esopus Spitzenberg) are taken from a case of genetic variegation.

from affected to healthy potted plants, or by grafting healthy scions on diseased plants. These tests were on a small scale and involved in some cases only one or two plants. The negative results are therefore not always conclusive.

Cotoneaster harroviana became affected after inoculation by inarching, with the production of pale bands and rings in the leaf blade. The symptoms were inconspicuous, but the virus was recovered without apparent loss of virulence by inoculation from this species to apple and rose.

The loquat, Eriobotrya japonica, developed strong chlorotic symptoms resembling those on the apple and in addition, in young leaves, a considerable amount of necrosis along the larger veins, resulting in marked distortion of some leaves (fig. 2). This necrosis developed under glass 
and was not preceded by any marked chlorosis as is the case with the apple. The virus was recovered from loquat by inoculation to rose.

Three of 5 plants of toyon (Photinia arbutifolia) developed symptoms during the year following inoculation. The chlorotic spots which resulted were similar to those on the apple but few in number.

Although it is difficult to obtain a graft union between the rose and

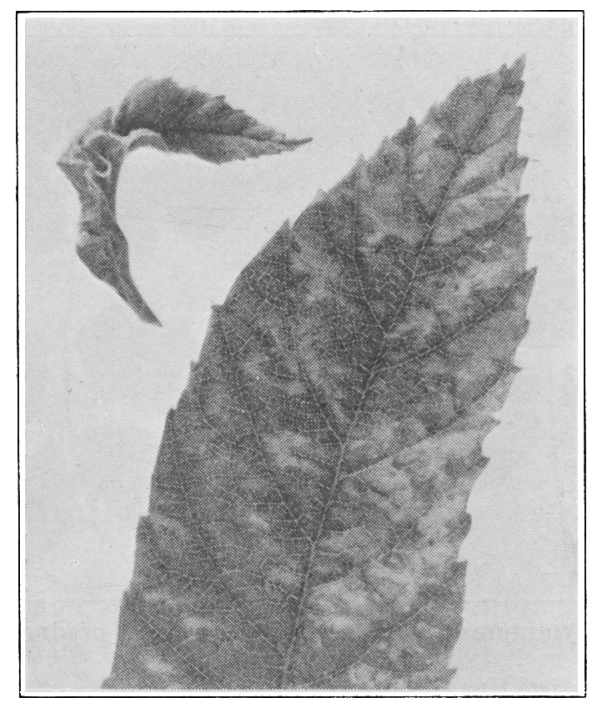

Fig. 2.-Mottling and leaf distortion of loquat produced by inoculation with the applemosaic virus.

members of the pome group, definite symptoms were obtained on 5 of 8 plants of Independence Day and Belle of Portugal roses which were inoculated by inarching with affected apple, Cotoneaster, or loquat (fig. 3 ). The virus was recovered from one of these roses by inoculation to apple. The symptoms vary appreciably and may include vein clearing on occasional leaves, but usually approach the type seen on the leaf at left in figure 3. From the type of symptom and the rate of development in the plant, it is inferred that this disease is distinct from the several virus diseases that have been found occurring naturally on the rose in central California.

A single plant of Sorbus pallescens inoculated by a scion of affected apple, developed rather strong symptoms resembling those on the apple.

Attempts to cause infection in Amelanchier alnifolia (western service berry), Crataegus douglasii (western black haw), Cydonia oblonga 
(quince), Pyracantha gibbsii yunnanensis (yunnan fire thorn), Pyrus communis (pear-Bartlett variety), and Sorbus sitchensis (western mountain ash) have failed, as have also the attempts to recover the virus from inoculated plants of Amelanchier, Crataegus and pear. Recovery was not attempted with the others in this group.

Thus far the discussion has dealt with what is presumed to be a single disease. Other types of chlorosis are not infrequently found on apple

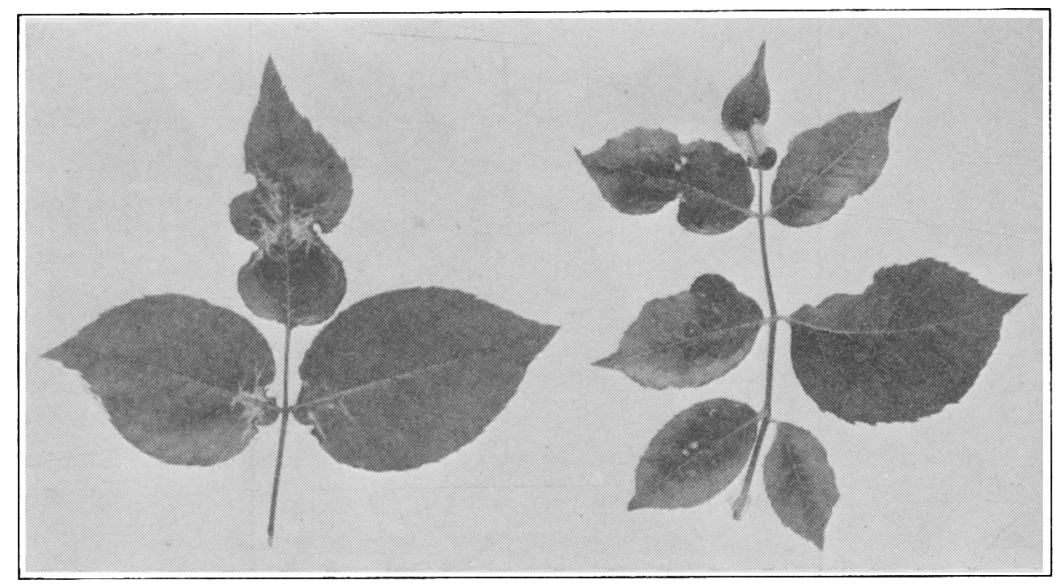

Fig. 3.-Symptoms on Belle of Portugal rose produced by the apple-mosaic virus.

foliage, some of which are not readily separated by symptoms alone from the typical mosaic. Of five such cases encountered without special search in a three-year period, three seemed to be definitely genetic in origin. One of these (fig. 1) was propagated at Berkeley and gave no evidence of transmission by grafting to healthy apple. In another case, a single orchard tree of the Tompkins King variety bore, on leaves scattered generally through the tree, symptoms that were not distinguished from those of the common mosaic. Scions from this tree were grown at Berkeley during the season of 1935 and additional ones in 1936. None of these developed any symptoms except two which were inoculated by inarching with known mosaic apple shoots. Three of the Tompkins King scions, after growing for one season at Berkeley, were top-worked with healthy scions of the susceptible Golden Delicious variety. The latter also remained free of symptoms except one inoculated as above with known apple mosaic. These results indicate that the agent which produces symptoms in the Tompkins King tree is distinct from the common mosaic virus and does not induce resistance to the latter. 
A tree of the kaido crab (Pyrus micromalus), growing in a garden at Berkeley, bore symptoms in 1933 suggestive of those figured for ornamental crab apple in Kentucky (Valleau, ${ }^{(9)}$ fig. 25). Two seedling loquat trees that were inarched with affected kaido shoots developed mild chlorotic symptoms and in a few leaves fine necrotic lines and rings, distinct in appearance from the symptoms produced in loquat by the virus of the common mosaic. Scions from the original kaido tree were grafted on a White Astrachan tree in 1933 but no symptoms have developed on the latter nor on Golden Delicious, which was later grafted on the same tree (January, 1935). When scions from this Golden Delicious were transferred nine months later to a plant affected by the common apple mosaic, the resulting Delicious foliage bore typical symptoms of the apple mosaic.

\section{DISSEMINATION AND MOVEMENT OF VIRUS IN THE PLANT}

Blodgett, who has demonstrated the transmissibility of the disease by grafts (see Orton and $\mathrm{Wood}^{(7)}$ ) and who has had this disease under observation in orchards of western New York, reports ${ }^{5}$ that during a fiveyear period there was little evidence of natural increase in the number of affected trees.

In the orchard at Paradise, symptoms are confined to the Ranier variety, where 22 of 53 trees were found affected in July, 1935. No new infections were found in May, 1936. None were found in several dozen trees of Delicious in the same orchard or in a block of Golden Delicious trees adjoining this orchard. The affected tree found in Berkeley was planted about fifteen years ago, yet several other trees in the same garden seemed to be entirely free from the disease. No case of spontaneous infection has been seen among the experimental plants.

While the incubation period may be as short as 53 days in apple inoculated by budding, the movement of the virus through the plant is slow, especially in the toyon and rose. When these plants were inoculated in July in one branch each about 6 inches above the base of the branch, the symptoms appeared near or above the point of inoculation the following spring but had not appeared in other branches after more than two years. One such rose plant did show symptoms on all branches after 27 months. ${ }^{\circ}$ These and other observations show that the virus moves more slowly toward the root than upward.

\footnotetext{
${ }^{5}$ Blodgett, F. M. Personal letter, November 11, 1935.

- With one of the naturally occurring rose mosaics, symptoms have been seen (in rose) below the point of inoculation in less than $\mathbf{4 0}$ days from the time of inoculation.
} 
Bearing upon the manner of dissemination are sap inoculations made on three different occasions on young leaves or stems of 12 seedlings of apple, 2 of Pyrus baccata, 5 of toyon, and 5 of Cotoneaster franchetti. Carborundum $^{(8)}$ was used as an abrasive on all of these. No certain symptoms were seen on any of the plants up to the time of writing, or more than 6 months after the last inoculation.

There is at the time of writing no direct evidence of dissemination by any means except by grafting. It is apparent, however, that, given an efficient natural vector, the disease is capable of affecting a considerable number of species with appreciable damage to certain of them.

\section{HEAT TREATMENT OF AFFECTED SCIONS}

One of the most promising methods of removing virus from a plant which is propagated vegetatively seems to be exposure of affected plants or plant parts to high temperatures. ${ }^{(5)}$ The expression of symptoms under varying temperature conditions (not controlled), suggests that the virus of apple mosaic has a relatively low optimum temperature.

\section{TABLE 1}

Effect of High Temperatures on the Mosaic Virus in Detached Dormant APPLE SHOOTS

\begin{tabular}{c|c|l|c|c|c}
\hline \hline Temperature & Time & Moisture & $\begin{array}{c}\text { Number } \\
\text { grafted }\end{array}$ & $\begin{array}{c}\text { Number } \\
\text { showing } \\
\text { symptoms }\end{array}$ & $\begin{array}{c}\text { Injury } \\
\text { to scions by } \\
\text { heating }\end{array}$ \\
\hline${ }^{\circ} C$ & & & & & \\
36 & 7 days & Moist sphagnum & 8 & 6 & Moderate \\
36 & 11 days & Dry air* & 5 & $0 \dagger$ & Severe \\
45 & 60 min. & In water & 8 & 8 & Slight \\
50 & 30 min. & Dry air & 13 & 10 & Slight \\
50 & 60 min. & Dry air & 8 & 6 & Slight \\
\hline
\end{tabular}

* The basal ends of these pieces were sealed in a vessel containing water. The portions exposed to the water were discarded.

$\dagger$ All of the scions died within 5 weeks.

In a preliminary test in 1935, a few affected shoots of apple were exposed for 15 and 30 minutes to an air temperature of $55^{\circ} \mathrm{C}$. Scions were taken from these and grafted on potted seedlings in the greenhouse. Of 3 such plants which made satisfactory growth, 1 failed to developp any symptoms during 1935. This plant did, however, bear mild symptoms toward the end of the summer of 1936. This plant was of the Gravenstein variety, which is less susceptible than some of the others tested. In the meantime in 1936, several experiments were made in which detached dormant apple shoots were exposed to different temperatures and condi-. 
tions of moisture and for different intervals of time. The shoots were taken from the last preceding growth cycle and were for the most part 4 to 8 millimeters in diameter. Scions from the heated shoots were grafted on potted apple seedlings and were grown in a lath-house at Berkeley. The details of these tests and the results are summarized in table 1. The failure of certain plants to develop symptoms is probably due to early death or to insufficient growth of the scions rather than to inactivation of the virus. The expression of symptoms here, as in many other virus diseases, is related to vigorous growth of the plant. Since several of the treatments were near the limit of tolerance of the apple tissues, it seems unlikely that heating of scions will be effective in freeing them from the mosaic virus. There was no recognized evidence of attenuation of the virus in these experiments. 


\section{SUMMARY}

An apple mosaic found in California seems to be identical with the disease known in the eastern United States.

The disease has been transmitted by grafting to Cotoneaster harroviana, Eriobotrya japonica (loquat), Photinia arbutifolia (toyon), Rosa sp. (rose, Belle of Portugal and Independence Day varieties) and Sorbus pallescens.

Heating dormant apple shoots in several ways to near the killing point of apple tissues did not inactivate the virus.

\section{LITERATURE CITED}

${ }^{1}$ BRAdFord, F. C., and Lloyd Joley.

1933. Infectious variegation in the apple. Jour. Agr. Research 46:901-8.

2 Christoff, Alexander.

1935. Mosaikfleckigkeit, Chlorose und Stippenfleckigkeit bei Apfeln Birnen und Quitten. Phytopath. Ztschr. 8:285-96.

${ }^{3}$ Edson, H. A., Paul R. Miller, and Jessie I. Wood.

1935. Diseases of plants in the United States in 1934. U. S. Dept. Agr. Bur. Plant Indus. Plant Disease Reporter Sup. 90:42. (Mimeo.)

${ }^{4}$ Heald, F. D.

1935. Division of Plant Pathology. In: Forty-fifth Annual Report. Washington Agr. Exp. Sta. Bul. 325:50-53.

${ }^{5}$ KUNKEL, L. O.

1936. Heat treatments for the cure of yellows and other virus diseases of peach. Phytopathology 26:809-30.

${ }^{6}$ Morse, W. J.

1916. Two apple-leaf troubles new to Maine. In: Spraying experiments and apple diseases in 1915. Maine Agr. Exp. Sta. Bul. 252:186-90.

${ }^{7}$ OrTon, C. R., and Jessie I. Wood.

1924. Diseases of fruit and nut erops in the United States in 1923. U. S. Dept. Agr. Bur. Plant Indus. Plant Disease Reporter Sup. 33:82. (Mimeo.)

${ }^{8}$ Rawlins, T. E., and C. M. Tompkins.

1934. The use of carborundum as an abrasive in plant-virus inoculations. (Abstract.) Phytopathology 24:1147.

- Valleau, W. D.

1932. A virus disease of plum and peach. Kentucky Agr. Exp. Sta. Research Bul. $327: 89-103$. 